\title{
An Analysis of the Cultural Phenomena in English and Its Translation
}

\author{
Xiao Geng \\ Qingdao University of Science and Technology \\ Qingdao 266003, China \\ E-mail: gxdonna@gmail.com
}

\begin{abstract}
Translation mostly takes place between languages. As we know, there are intimate relations between languages and culture. Language and culture, like content and form, live upon and affect each other. As a cross - cultural event, translation is influenced largely by the culture in the source language. So it is vital to analysis the culture in the original language before we set about translating. The essential points this paper treats are analysis of the cultural phenomena in English. This paper also means to stimulate more concentration on the approaches to deal with the cultural phenomena in translating. Further, this paper points out several problems commonly seen in dealing with the cultural phenomena.
\end{abstract}

Keywords: Translation, Language, Culture, Cultural phenomena

\section{Introduction}

The definition of translation varies according to different people. Although definitions do not mention the cultural factors in translation practice, we should be clearly aware that translation acts as a bridge to connect two different cultures by the conversion of linguistic systems. Translation is a media by which people with different linguistic and cultural backgrounds can make intercourse or interchange their ideas.

Some sociologists and anthropologists believe that culture is the integration of belief, custom, system, object, and technique. Knowing the cultural phenomena is of most importance for setting up a cultural point of view in translation. In fact, a translator often encounters difficulties due to cultural diversities. Among nations the difference in nation, geographical location, religious belief, value view, political institution, etc. causes the cultural distinction. Furthermore, the difference of nation experience and psychology can be found in languages. Thus the cultural influence on language makes the main obstruction in translating. It is completely necessary to make an analysis of the cultural phenomena before translating.

\section{The cultural phenomena}

English vocabulary plays a crucial part in learning English. "Learning a foreign language basically a matter of learning the vocabulary of that language." (Willace, Michael J., Teaching vocabulary, 1982, P.9) the cultural elements are largely accumulated during the long historical development of the English vocabulary. For translators, this means that they should have some idea about the cultural phenomena in English vocabulary as well as about itself. This article tries to study the cultural phenomena in English in terms of word, idiom, and allusion.

\subsection{The cultural phenomena in words}

Fan Ke, in his Word Origin said, "Vocabulary, with its rich legends and stories, leads us into fables and history, helping us know a lot of great figures and important events. Vocabulary is also like a window through which we can get familiar with the past of a nation."

Shopping----bag ladies make up a peculiar portion of New York's populace.

Shopping----bag ladies: women who have no fix living place and have to live and sleep in the street .They put all that they possess into a few of shopping bags that they take with them all the time. In fact, they are not real beggars, although they all look like beggars. 


\subsection{The cultural phenomena in idioms}

English idioms form an essential part of the general vocabulary. Idioms reflect the environment, life, history and culture of the native speakers, closely associated with their innermost spirit and feelings. Idioms have so close relationship with historical background, economy, geographical environment, custom, etc. of the nation concerned that they more typically represent the cultural characteristics of a language than words. Examples are abundant to show that.

Several of the country's most respected doctors have stated that smoking cigarettes harms one's heart, but there are still many doubting Thomases who are not yet persuaded.

Doubting Thomas: This idiom came from a story in Bible. Jesus was nailed on the cross - rack and died. He revived and came to see his disciples. Tomas, one of his disciples, didn't see Jesus himself, so he didn't believe Jesus really revived. After that doubting Thomas was used to refer to incredulous people.

\subsection{The phenomena in allusions}

Allusion refers to some person or event, either historical or fictional. It has dramatic and vivid connotation and is often used in speech and writing. English has a tremendous amount of allusion, which result from mythology, legends, fables, fairy tales, the Bile, famous literary words, historical figures or events. So allusion can reflect typically and intensively the cultural phenomena in English.

Romeo: Well, in that hit you miss; she'll not be hit by Cupid's arrow.

Cupid's arrow: cupid, the roman god of love, representing love. When we say that a girl is hit by cupid's arrow, we mean that she gets love from a boy. This allusion is used widely in literary works.

Language is a cultural phenomena meanwhile a social one. And language is the main part of culture, at the same time the carrier of culture. The cultural phenomena in words, idioms and allusion, which we talked about above, show that language and culture live upon each other. So it is very necessary to know of the cultural phenomena in a language before we translate it into Chinese. Being aware of that point is extremely helpful in translating practice. After we made some analysis of the cultural phenomena in terms of words, idioms and allusion, the next step is how to translate these cultural phenomena.

\section{Approaches of translation about cultural phenomena}

About cultural phenomena in English methods of translation vary according to different original text. The following several methods are commonly used.

\subsection{Literal translation and free translation}

\subsubsection{Literal translation}

The literal translation is not word-to-word translation but translation that doesn't need so much extending text. Let's see one example.

Borrowed garment never fits well.

\subsubsection{Free translation}

Under some conditions, the readers cannot accept literal translation, which might confuse them. If this happens, free translation is used to keep the intact content of the original work, though some cultural feature is lost. Owing to cultural difference, free translation is used more frequently. One example is abundant.

I'm Dutchman if I go.

\subsubsection{The literal translation plus the free translation}

To make the original meaning clear, vivid and easy understood, sometimes a translator must use both the literal translation and free translation.

If you had told Sycorax that her son Caliban was handsome as Apollo, she would have been pleased, witch as she was.

\subsection{Foreignization and domesticalization}

In the process of translation, we often face contradiction between "to strive for easy-understood." and "to preserve the original style". This is a question about foreignization and domesticalization. Someone insists on Nationalization so as to meet the psychological habits of Chinese readers; others advocate thoroughly foreignization so that foreign flavor can be maintained. However, these two points of view are all too extreme. Foreignization and domesticalization should go along with each other and complement each other. In dealing with cultural phenomena, we should try to appropriately use these two methods. Some rules must be followed:

Foreignization gives expression to the national style and characteristic of the original text, reflecting the cultural character of the source language. 
Both foreignization and domesticalization are methods of translation. Translation introduces the foreign culture, on the other hand, the important part of the culture of our own country. Whichever method of this two is used, the final aim is to gain the best translation, Let's see some examples:

$<1$.> The three children set out for Sunday School, a place that Tom hated with his whole heart; but Sid and Mary were fond of it.

三个孩子一起动身上主日学校, -这地方是汤姆深恶痛绝的; 可是西德和玛丽却颇有好感。(Foreignization)

$<2$.> He was the open sesame to a new and glittering world that excited me as nothing in my life had ever done before.

他像一把打开通向崭新而光彩夺目世界的钥匙, 使我觉得在我的生活中从未有过这样的激动。

(Domesticalization)

The four methods above-mentioned are only the basic methods that we frequently use in translating. In fact the methods in translating are not confined to the above four. It's the translator who makes the decision freely on which method to take in dealing with the cultural phenomena of the source language. But this doesn't mean that we must use this or that method in translating the cultural phenomena. In some cases, several methods may be available in translating a cultural phenomena. The translator can flexibly choose any method. No matter you choose the literal translation or free transition, foreignization or domesticalization; the final purpose is identical, i.e. to get a translation in terms of faithfulness and smoothness.

\subsection{Related problems in translating the cultural elements into Chinese}

Translation is a practice of intercultural communication. Thanks to the cultural difference between Chinese and western, how to translate the cultural factors is, especially to a new translator, always a difficult point. We must pay enough attention to the following problems arising in dealing with the cultural phenomena.

\subsubsection{Word-to-word translation}

The literal translation needs little extending and notes, however, doesn't mean that we always take word-to-word translation for granted. If that, we may make a laughing stock of ourselves before expert. Let's see one example:

To my joy, my son knows a thing or two about Italian.

Wrong: 使我高兴的是, 我儿子对意大利也略知一二。

Right: 使我高兴的是, 我儿子对意大利语还很精通哩。

"Know a thing or two" refers to "to have practical and useful information gained from experience", in Chinese not “略 知一二”, but “非常熟悉, 了如指掌”.

\subsubsection{Over-representation or over-flowery translation}

In translating we don't overstress the role of literal translation since free translation is sometimes imperative. But free translation isn't arbitrary and unrestrained. In free translation, over-representation or over-flowery translation is a problem commonly seen. Let's see one example.

He had lived for about eight years of his life, quite alone, at this charming place, scarcely seeing a Christian face.

他在这有趣的地方一个人过了 8 年，终年见不到一个信仰基督教的文明人。

Here, the free translation of “a Christian face” is “文明人”. not “信仰基督教的文明人”, thus”信仰基督教的” is unnecessary.

\subsubsection{Tendency of English-Chinese}

In dealing with cultural phenomena, especially in using Foreignization, many English-Chinese translations are made. We advocate retaining the tone and mood of foreign language so as not to lose the social and historical characteristic of original material, but meanwhile we must avoid translation. Let's see one example:

Mother is the boss in her kitchen.

Wrong: 妈妈是㕑房里的老板。

Right: 妈妈负责做饭

In translating, many problems deserve our attention. The several problems above-mentioned are commonly seen in dealing with the cultural elements in English-Chinese translation. Since they are problems, we should try to avoid them or correct them.

\section{Conclusion}

Shortly, translation is to transform one language (the source language) into another language (the target language). Translating is an intercultural practice as well as a bilingual one, so it concerns two different languages, meanwhile two 
different cultures. Language and culture depend on each other for survival and neither of them can exist solely. We must know of the culture before we really understand a language, visa versa. Due to the diversity of nation, geographical lotion, religious belief, view of value, political institution, cultural difference is inevitable. Language is the direct object of translation and influenced largely by culture, so cultural diversity inevitably influences translation. That is just the main barrier in translating. In English-Chinese translation, the quality of translation relies, to large extent, on the translation about cultural factors. Before translating, we should first of all study the cultural phenomena in English (here mainly words and phrases) in order to comprehend accurately the original text. Then on this basis, subject to the feature of the original material, the methods of translation can be chosen flexibly. It may be the cultural Reservation (literal translation or foreignization) that can reflect the original style and feature and rebuild the original mentality of other nations and cultural characteristic, or the cultural interpretation (Free translation or domesticalization) that can meet the national and linguistic habits of the native receptors, so as to ensure the readability of translation. Besides, several common false tendencies in translating should be attached great attention to and corrected. In conclusion, we should study profoundly the cultural phenomena in source language, and take flexible methods to attain a good attain a good translation.

\section{References}

Bassnett, S and A. Lefevere. (1987). Translation, history and culture. Oxford: Pergamon.

Jia, Qin. (2001). Do not to Translate Idioms from the Literal Meaning. English Learning.

Marry Snell-Hornby. (2001). Translation study: An integrated approach. Shanghai foreign language education press.

Wang, Zhikui. (1999). A Guide to College English-Chinese Translation. Shandong University Press.

Wolfram, wilss. (2001). The science of translation: Problems and Methods. Shanghai foreign language education press.

Wu, Wenzhong. (1999). Aspects of International Cultures. Foreign Language Teaching and Research Press.

Zhang, Yunwen. (1987). Modern English Lexicology. Beijing Normal University Press. 